\title{
Use of the ESI-2007 scale to evaluate the 2003 Boumerdès earthquake (North Algeria)
}

\author{
Aicha Heddar ${ }^{1}{ }^{\star}$, Hamoud Beldjoudi $^{1}$, Christine Authemayou ${ }^{2}$, Roza SiBachir ${ }^{1}$, \\ Abdelkrim Yelles-Chaouche ${ }^{1}$, Azzedine Boudiaf ${ }^{3}$ \\ ${ }^{1}$ Centre de Recherche en Astronomie Astrophysique et Géophysique (CRAAG), Bouzareah-Algiers, Algeria \\ ${ }^{2}$ Institut Universitaire Européen de la Mer Technopôle Brest-Iroise, Plouzané, France \\ ${ }^{3}$ Consultant Geologist, Sète, France
}

\author{
Article history \\ Received November 18, 2015; accepted April 27, 2016. \\ Subject classification: \\ Boumerdès earthquake, Algeria, Earthquake environmental effects, Intensity, ESI-2007 scale, Seismic hazard.
}

\begin{abstract}
In this study, we applied the environmental seismic intensity (ESI-2007) scale to a major recent Algerian earthquake. The ESI-2007 scale is an effective tool to assess the seismic hazard and has been applied to onshore earthquakes. Here we applied the scale to a recent earthquake ( $M w$ 6.8, 2003) that took place offshore in the province of Boumerdès in the north of Algeria along the boundary between African and Eurasian plates. The main shock was associated to an unknown submarine structure. No surface ruptures were observed on the onshore domain, but many earthquake environmental effects (EEEs) were reported during several field investigations. In addition to onshore ground effects, this event triggered turbidity currents responsible for 29 submarine cable breaks. Mapping and describing coseismic ground effects allowed us to distinguish primary and secondary effects like coastal uplifts, liquefaction phenomena, tsunami waves, turbidity currents, cracks, rock falls, slope movements and hydrological anomalies. Considering the total area affected and the distribution of ground effects, we suggest intensity $X$ that appears in agreement with intensity calculated in previous study with the EMS-98 scale. Thus, this method is validated even in the case of a coastal earthquake, and could be applied in the future to Algerian historical earthquakes that have affected scarcely inhabited zones but where EEEs were listed and located.
\end{abstract}

\section{Introduction}

Earthquake environmental effects (EEEs) are any effects produced by a seismic event on the natural environment [Michetti et al. 2007]. They are generally integrated in traditional intensity scales to some extent; however, damages affecting man-made structures are mostly used to assess macroseismic intensities. When not destroyed by erosion or anthropogenic action, these coseismic environmental effects are preserved in upper soil layers and may become valuable geological archives. They are used in paleoseismology allowing to extend the time window for analyzing seismic hazards up to tens of thousands of years [Michetti et al. 2007, Porfido et al. 2007]. Thus, progress in the field of earthquake geology and paleoseismology where special attention is given to geological effects [Allen 1975, Audemard and Michetti 2011] contributed to the development of the ESI scale in 2007. One of main results of the INQUA (International Union for Quaternary Research) subcomission group during the last decade was the implementation of the EEE catalogue and the validation of the ESI scale [Michetti et al. 2004, 2007]. This relatively new intensity scale based only on the EEEs and regardless of human parameters has been successfully applied in various tectonic settings worldwide both on moderate and strong events [Michetti et al. 2007, Reicherter et al. 2009]. The method uses numerous EEEs that can be observed in all kind of climatic regions within an onshore or coastal offshore context [i.e. Audemard et al. 2015]. Nowadays, it is largely demonstrated by studies on historical or modern earthquakes that the ESI-2007 scale allows more objectivity in assessing macroseismic intensities [Michetti et al. 2004, Serva et al. 2007, Papanikolaou et al. 2009], whereas traditional intensity scales are influenced by human parameters such as man-made and economic development. Indeed, it has been observed that earthquakes with the same magnitude might not have the same intensity according to whether they occur in a developed or developing country because the building standards used are not the same. Moreover, the ESI-2007 scale provides other benefits such as the possibility to assess seismic intensity in sparsely populated or inhabited areas, or to evaluate the intensity when traditional scales saturate (i.e. for intensity X to XII) and only the coseismic environmental 
effects are considered for diagnosis [Michetti et al. 2004]. Despite these advantages, this scale has nevertheless limitations [Papanikolaou et al. 2009]. Mainly, it is considered less precise for deep events where ruptures cannot reach the surface, and its application is recommended only in the epicentral area (near field) where ground effects occur and concentrate. Currently, the potential of EEEs in the seismic hazard assessment becomes increasingly obvious, and the ESI-2007 scale is almost systematically used alongside traditional scales.

In Algeria, we traditionally used the MM (modified Mercalli) and the MSK (Medvedev-SponheuerKarnik) scales to estimate the macroseismic intensity. Since the Boumerdès 2003 earthquake that occurred fifty kilometers east of Algiers, we applied the macroseismic EMS-98 intensity scale [Grünthal 2001], except that the latter designed for European standards is not appropriate to our local conditions where the building quality is heterogeneous (different historical periods). Adding to this, the current housing crisis has led to an uncontrolled urbanization where standards and construction techniques are not respected.

In this study, we propose to introduce the environmental seismic intensity (ESI-2007) scale as a new tool to assess seismic hazard in Algeria and we chose to apply it to the Boumerdès, May 2003 (Mw 6.8) earthquake. Although no surface rupture was observed on land during this event, the Boumerdès earthquake triggered many geological effects. Our study aims to assess the macroseismic intensity with the ESI-2007 scale combining the onshore and offshore data that have been scarcely considered in the EMS-98 scale, and to compare the results with those obtained in a previous study [Harbi et al. $2007 \mathrm{~b}]$ in order to validate the method despite difficulties. Indeed, this earthquake occurred in a highly urbanized area where observation and mapping of ground effects have been difficult to carry out. During macroseismic investigations the information gathered were mostly concentrated on damage to man-made structures. Through this study we draw attention to the usefulness

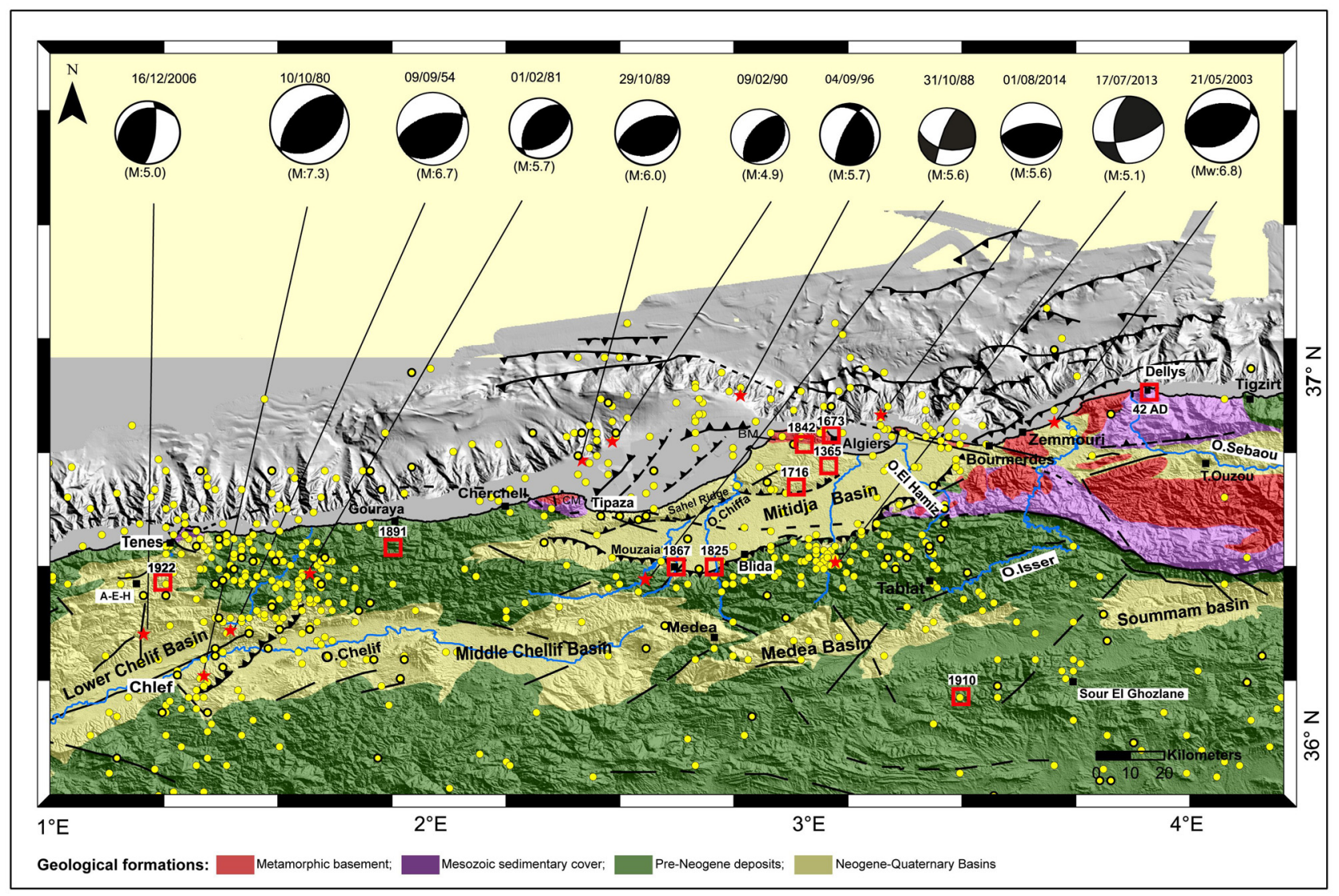

Figure 1. Seismotectonic map of Algiers and its surroundings. Shaded relief bathymetry from MARADJA2003 and MARADJA2005 cruises [Déverchère et al. 2005, Domzig et al. 2006, Kherroubi et al. 2009] and topography onland (90 m-SRTM DEM) map showing offshore faults [Domzig et al. 2006, Ayadi et al. 2008, Strzerzynski et al. 2010] and onshore faults [Meghraoui et al. 1988, Boudiaf 1996, Yelles et al. 2006] (back lines). Focal mechanisms of main shocks ( $\mathrm{Mw}>4.9)$ [Deschamps et al. 1982, Delouis et al. 2004, Beldjoudi et al. 2011; ING, Instituto Geográfico Nacional, http: / / www.ign.es; GFZ, German Research Centre for Geosciences, www.gfz-potsdam.de; Harvard GCMT, Harvard Global Centroid-Moment-Tensor, http:/ / www.globalcmt.org/] after 1980 are plotted as red stars. Red open squares show the location of significant historical earthquakes [Rothé 1950, Benouar 1994, Mokrane et al. 1994, Harbi et al. 2007a]. White dots correspond to instrumental seismicity $(M>3)$ [Benouar 1994, Mokrane et al. 1994, Yelles-Chaouche et al. 2002, Yelles-Chaouche et al. 2011, Annual bulletins from Craag 2012 to 2015]. MC and MB show the Chenoua and Bouzareah Massifs, respectively. 
and relevance to map the geological ground effects following an earthquake. These data could help us to identify suitable sites for paleoseismologic investigations, particularly in areas where the return periods are long.

\section{Seismotectonic setting}

The study area is situated in the Tell Atlas (northern Algeria), an orogenic zone seismically active due to the convergence between African and Eurasian plates. The current tectonic activity concentrates on folds and thrust faults trending NE-SW to E-W (Figure 1) onshore and offshore [Meghraoui et al. 1986, Morel and Meghraoui 1996, Déverchère et al. 2005]. Geodynamically, the Tell Atlas corresponds to the passive margin of the Algerian back-arc basin, produced by the rollback of the Tethyan oceanic slab subducting under the Kabylian blocks until the Miocene collision of these blocks with the African plate [Carminati et al. 1998, Gueguen et al. 1998, Vergès and Sabàt 1999, Frizon De Lamotte et al. 2000, Jolivet and Faccenna 2000, Duggen et al. 2004, Mauffret et al. 2004, Schettino and Turco
2006]. Currently, the convergence between the two plates reactivates this margin in compression [Thomas 1976, Domzig et al. 2006, Serpelloni et al. 2007].

Modern seismicity of the study area shows moderate activity punctuated by large earthquakes (Figure 1) associated to reverse faults. Historical seismicity reports some damaging events (Table 1) around Algiers (1365 AD, $1716 \mathrm{AD}$, and $1825 \mathrm{AD}$ ) with intensities up to $\mathrm{X}$ (EMS98) for the two first events [Harbi et al. 2007a], and up to X-XI (Mercalli) intensity for the last one [Rothé 1950]. Paleoseismological studies indicate recurrence intervals from 300 to 500 yrs for major earthquakes [Meghraoui et al. 1988, Heddar et al. 2013].

On May 21, 2003, a major earthquake occurred in the eastern part of the Mitidja Basin (Figure 2), an elongated EW-trending coastal intermountain Quaternary basin, affected by N-S to NNW-SSE-trending shortening [Thomas 1985, Meghraoui and Doumaz 1996]. This basin which drains into the Mediterranean Sea through the Bay of Algiers, is bounded to the north and to the south by two active structures. In the north, the Sahel

\begin{tabular}{|c|c|c|c|c|c|}
\hline Year & Latitude & Longitude & Intensity & Site & References \\
\hline 42 & $36.92^{\circ} \mathrm{N}$ & $3.89^{\circ} \mathrm{E}$ & - & Dellys & Ferdi and Harbi 2013 \\
\hline 1365 & $36.77^{\circ} \mathrm{N}$ & $3.05^{\circ} \mathrm{E}$ & X (EMS98) & Algiers & Harbi et al. 2007a \\
\hline 1673 & $36.77^{\circ} \mathrm{N}$ & $3.05^{\circ} \mathrm{E}$ & VIII (MM) & Algiers & Mokrane et al. 1994 \\
\hline 1716 & $36.67^{\circ} \mathrm{N}$ & $2.95^{\circ} \mathrm{E}$ & IX (EMS98) & Algiers & Harbi et al. 2007a \\
\hline 1825 & $36.45^{\circ} \mathrm{N}$ & $2.75^{\circ} \mathrm{E}$ & X-XI (M) & Blida & Rothé 1950 \\
\hline 1842 & $36.77^{\circ} \mathrm{N}$ & $3.05^{\circ} \mathrm{E}$ & VIII (MM) & Alger & Mokrane et al. 1994 \\
\hline 1867 & $36.42^{\circ} \mathrm{N}$ & $2.68^{\circ} \mathrm{E}$ & $\mathrm{X}-\mathrm{XI}(\mathrm{M})$ & Mouzaïa & Rothé 1950 \\
\hline 1891 & $36.56^{\circ} \mathrm{N}$ & $1.85^{\circ} \mathrm{E}^{\circ} \mathrm{E}$ & IX (EMS98) & Gouraya & Maouche et al. 2008 \\
\hline 1910 & $36.17^{\circ} \mathrm{N}$ & $3.4^{\circ} \mathrm{E}$ & VIII(MSK) & Sourel Ghozlane & Benouar 1994 \\
\hline 1922 & $36.4^{\circ} \mathrm{N}$ & $1.3^{\circ} \mathrm{E}$ & VII (MM) & BAH (Ténès) & Benouar 1994 \\
\hline
\end{tabular}

Table 1. List of the most important historical earthquakes mentioned in the Algerian catalogues.

\begin{tabular}{|c|c|c|c|c|}
\hline Locality & Longitude/ Latitude & Distance from epicenter $(\mathbf{k m})$ & Uplift (cm) & ESI-2007 intensity \\
\hline Algiers harbor & $3.06^{\circ} \mathrm{E} / 36.76^{\circ} \mathrm{N}$ & 53 & $4-5$ & IX \\
\hline Boudouaou & $3.38^{\circ} \mathrm{E} / 36.77^{\circ} \mathrm{N}$ & 24 & 75 & $\mathrm{X}$ \\
\hline Boumerdes & $3.47^{\circ} \mathrm{E} / 36.76^{\circ} \mathrm{N}$ & 18 & 55 & $\mathrm{X}$ \\
\hline Zemmouri harbor & $3.56^{\circ} \mathrm{E} / 36.80^{\circ} \mathrm{N}$ & 9 & 30 to 70 & $\mathrm{X}$ \\
\hline Sidi daoud & $3.85^{\circ} \mathrm{E} / 36.85^{\circ} \mathrm{N}$ & 18 & 55 & $\mathrm{X}$ \\
\hline Cap Djinet & $3.71^{\circ} \mathrm{E} / 36.87^{\circ} \mathrm{N}$ & 7 & 35 to 55 & $\mathrm{X}$ \\
\hline Dellys & $3.90^{\circ} \mathrm{E} / 36.91^{\circ} \mathrm{N}$ & 24.5 & 35 to 55 & $\mathrm{X}$ \\
\hline Tigzirt & $4.12^{\circ} \mathrm{E} / 36.89^{\circ} \mathrm{N}$ & 42 & 2 & VIII \\
\hline
\end{tabular}

Table 2. Estimation of ESI-2007 Intensity considering coseismic uplift (primary effect). Measures are after Bouhadad et al. [2004] and Meghraoui et al. [2004]. 


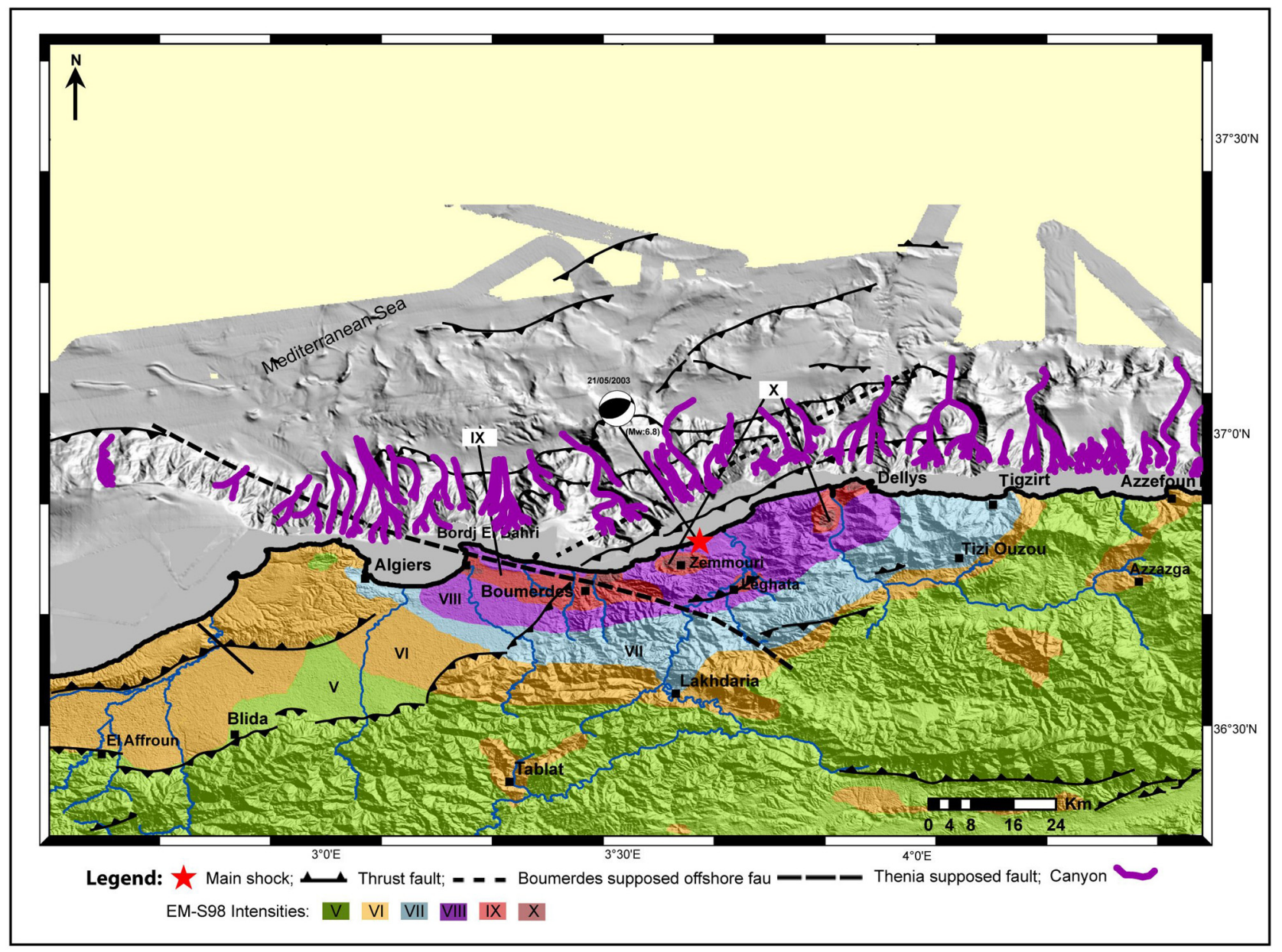

Figure 2. Seismotectonic map of Boumerdès and the surrounding area. Main shock [Bounif et al. 2004], focal mechanism [Delouis et al. 2004] and faults are from Meghraoui et al. [1988], Déverchère et al. [2005], Domzig et al. [2006], Ayadi at al. [2008], Strzerzynski et al. [2010]. The background is shaded topographic (90 m-SRTM DEM) map wrapped with the EMS-98 isoseismal map (from Harbi et al. [2007b]).

ridge runs along the coast and links the Chenoua to the Algiers-Bouzareah massifs that are relics of Kabylian blocks [Durant-Delga 1969]. This structure is bounded to the south by a $60-\mathrm{km}$ long, NW-dipping blind thrust fault [Meghraoui 1991] which is assumed to be the main source of seismic hazard for the region of Algiers [Meghraoui 1991, Harbi et al. 2004, Maouche et al. 2011, Heddar et al. 2013]. To the south, the basin is limited by the ENE-WSW-trending en-echelon reverse Blida fault system located at the foot of the Blidean Atlas Mountains showing Mesozoic and Cenozoic formations overthrusting Neogene and Quaternary layers [Boudiaf 1996, Yelles et al. 2006, Guemache et al. 2010]. The fault activated during the Boumerdès earthquake likely corresponds to the eastward extension of the Blida fault system [Meghraoui et al. 2004].

Seismic monitoring in the area around Boumerdès prior to 2003 was insufficient and seismic hazard was considered relatively low [Yelles-Chaouche et al. 2003]. Historical information concerning ancient earthquakes that occurred in Algeria prior to the 14th century are scarce or non-existent. Nevertheless, the region of Algiers and its vicinities have experienced several histori- cal events in the past (Table 1). The 1365 earthquake of Algiers triggered sea waves in the lower parts of the city of Algiers. The 1716 earthquake, which claimed about 20,000 lives [Mokrane et al. 1994] and the Blida 1825 earthquake that struck the southern side of the Mitidja basin [Rothé 1950, Ambraseys and Vogt 1988, Mokrane et al. 1994] both affected Algiers. Moreover, according to archaeologists and historians, Dellys, an ancient Roman city situated $50 \mathrm{~km}$ east of Boumerdès on the coast, was destroyed by an earthquake during the Roman period at about $42 \mathrm{AD}$ [Harbi et al. 2007b, Ferdi and Harbi 2013].

\section{The 2003 Boumerdès earthquake sequence}

The Boumerdès earthquake is the most significant earthquake recorded in Algeria since the $1980 \mathrm{El}$ Asnam event $(\mathrm{Ms}=7.3)$. It affected a heavily urbanized and densely populated area (Boumerdès and the eastern Algiers provinces), and was felt within $\sim 400 \mathrm{~km}$ radius across the country, causing considerable damage and more than 3,000 victims. The main shock was located on the coastline [Yelles-Chaouche et al. 2003, Bounif et al. 2004]. The focal mechanism obtained indicates a re- 
verse fault striking NE-SW and dipping SE [Delouis et al. 2004] (Figure 2). The area recorded a peak ground acceleration (PGA) of $0.58 \mathrm{~g}$ in $20 \mathrm{~km}$ distance from the epicenter. $150 \mathrm{~m}$ away from this station another PGA of $0.34 \mathrm{~g}$ was recorded, both of them with a central frequency of $5 \mathrm{~Hz}$ [Laouami et al. 2006]. A huge number of aftershocks were recorded, reaching up to magnitude 5.8. According to Bounif et al. [2004], aftershocks dissemination on land and offshore suggest the offshore extension of the continental Blida thrust fault system that showed no significant seismic activity since the 1825 earthquake [Meghraoui et al. 2004]. Other scenarios, indicating an earthquake source on offshore reverse faults located at the foot of the margin, are also put forward [Déverchère et al. 2005, Domzig et al. 2006, Ayadi et al. 2008, Déverchère et al. 2010] (Figure 2).

This shallow event $(<10 \mathrm{~km})$ triggered a large set of ground effects such as coastal uplift, liquefaction features and other environmental effects that have been recognized in the epicentral area. Offshore, the earthquake triggered large turbidity currents responsible for 29 submarine cable breaks (Figure 5) [Harbi et al. 2007b, Cattaneo et al. 2012], and tsunami waves up to $1.5 \mathrm{~m}$ height [Alasset et al. 2006] recorded along the Spanish coast. The macroseismic intensity attributed to this event is $\mathrm{X}$ on the EMS-98 scale [Harbi et al. 2007b] (Figure 2).

\section{Spatial distribution and description of earthquake environmental effects}

The Boumerdès earthquake did not produce surface ruptures on land. Ground effects, however, were spread in a perimeter oriented ENE-WSW along the shoreline covering six provinces. The EEEs are mainly concentrated close to the coast (Figure 3). Eight categories of coseismic environmental effects have been catalogued, essentially uplift, liquefaction phenomena, mass movements, ground cracks and rock falls, hydrological anomalies, tsunami waves, and turbidity currents. The first four effects are located in the epicentral area (Figure 4, Table 3). They concentrate between Algiers and Tigzirt village (Figure 3), while rock falls appear in the periphery of this perimeter. Offshore mass wasting processes damaged cables (Figure 5) along a $150 \mathrm{~km}$ track between Algiers and Azzefoun, inducing a break in communication systems for a few days.

In their work on EEEs, Audemard and Michetti [2011] classify the earthquake environmental effects in 3 types designated A, B and C and distinguish those directly associated with the fault surface rupture (Type C, primary effects in ESI-2007scale), and the features not in direct contact with the fault plane called indirect or off-fault evidences (Types A and B, sec-

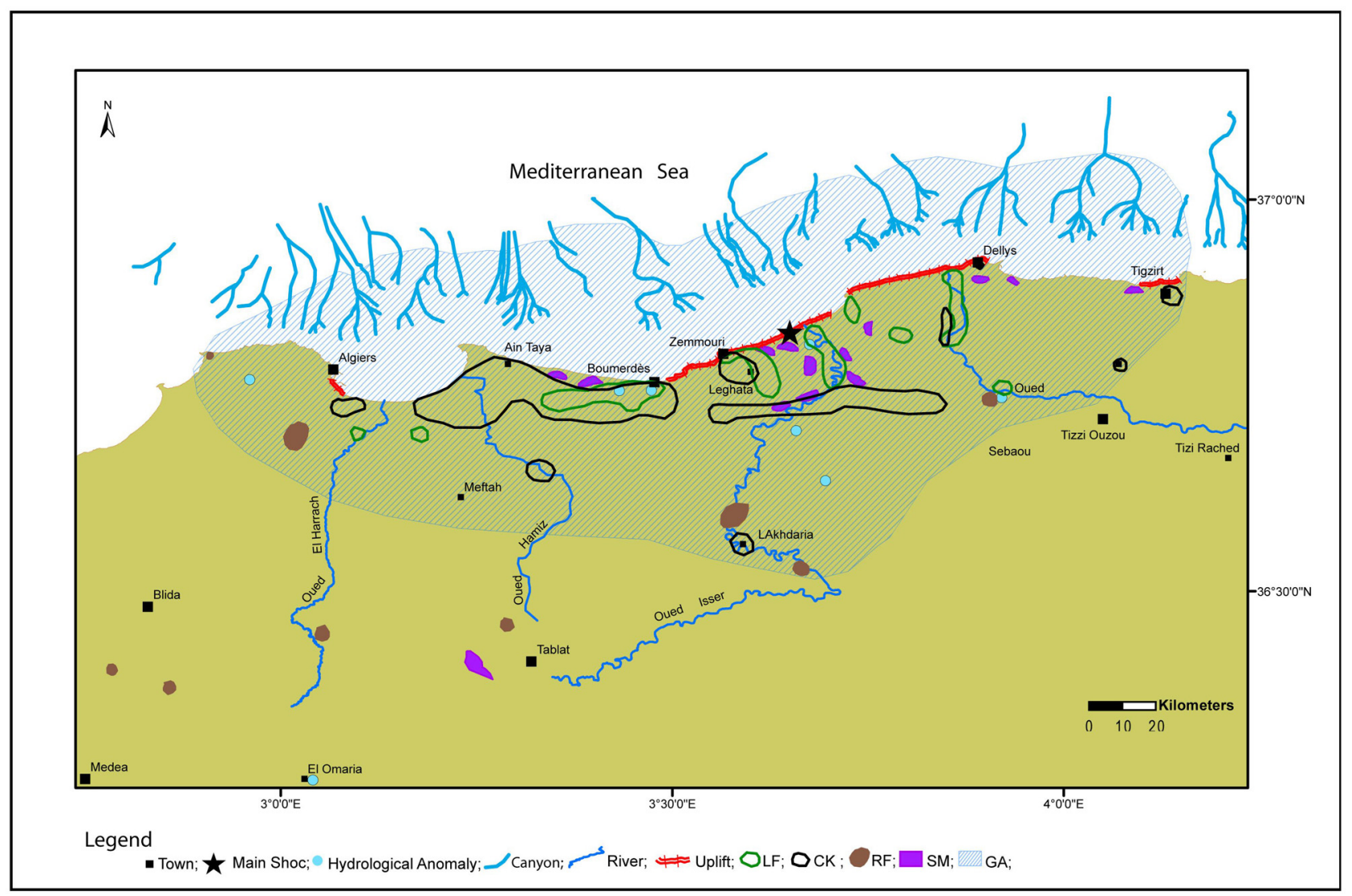

Figure 3. The 2003 Boumerdès earthquake geological effects distribution based on survey data from authors cited in the text, and the calculated global area. LF: liquefaction; CK: cracks; RF: rock falls; SM: slope movements; GA: global area. 


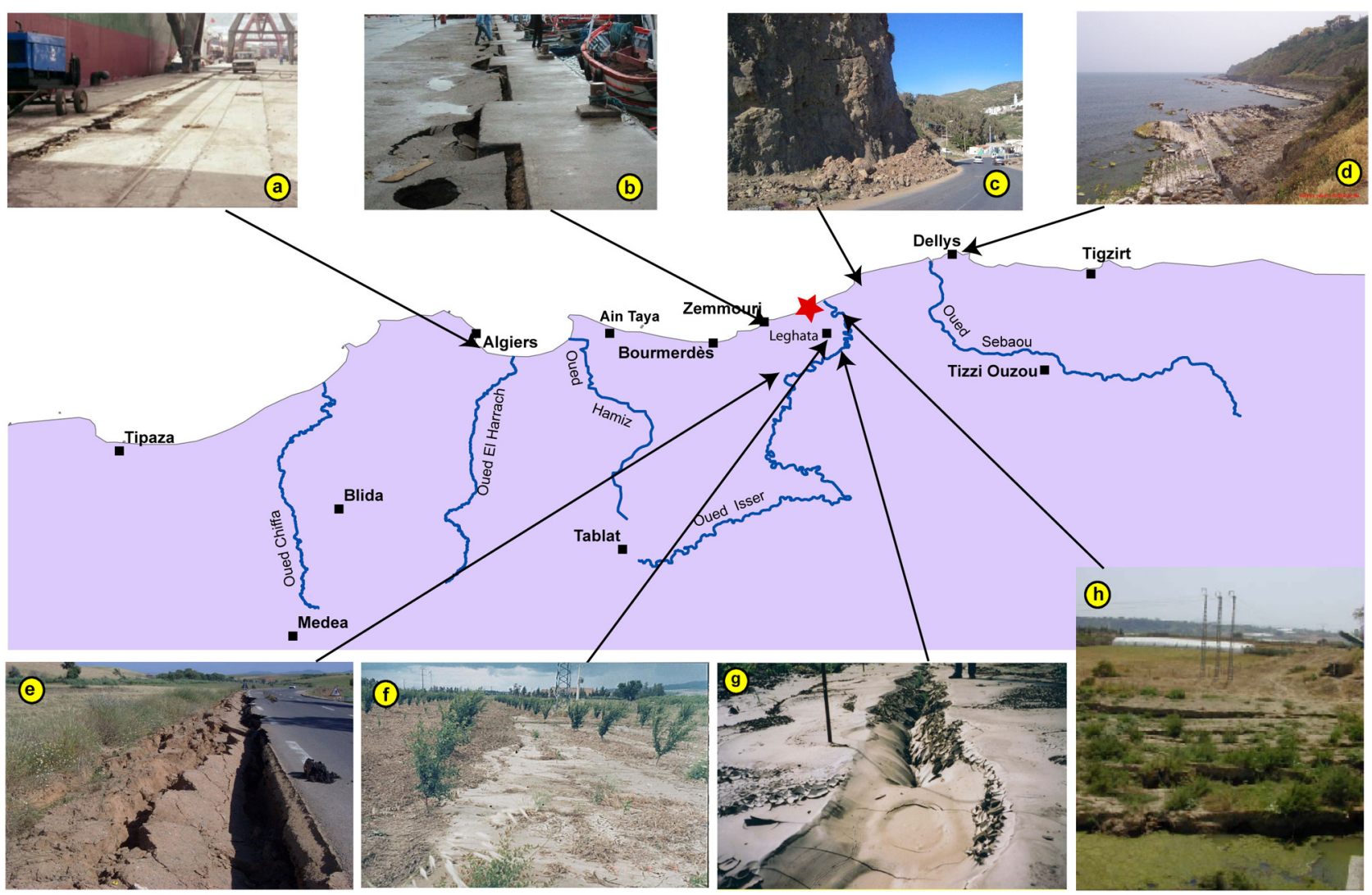

Figure 4. Ground effects observed after the Boumerdès earthquake. (a), (b) Photos of damage observed in Algiers Harbor and Zemmouri Harbor (close to the epicenter), respectively, with ground settlement $>30 \mathrm{~cm}$; (c) rock falls alongside NR 24 between Zemmouri and Dellys villages; (d) coastal uplift of about $50 \mathrm{~cm}$ near Dellys village (the white level is the uplifted seafloor); (e) cracks along national road south of Zemmouri village; (f) liquefaction-induced sand flow into an irrigation ditch in Zemmouri; (g) liquefaction-induced sand boils near Isser River; (h) tension cracks caused by lateral spreading of the river bank of Isser River; Red star: main shock.

\begin{tabular}{|c|c|c|c|c|c|}
\hline Photo & $\begin{array}{l}\text { Photo source } \\
\text { (Author) }\end{array}$ & $\begin{array}{c}\text { Date } \\
(\mathrm{dd} / \mathrm{mm} / \text { yyyy })\end{array}$ & Longitude/ Latitude & $\begin{array}{l}\text { Distance from } \\
\text { epicenter }(\mathrm{km})\end{array}$ & Geographic context \\
\hline (a) & CRAAG & $22 / 05 / 2003$ & $3.06^{\circ} \mathrm{E} / 36.76^{\circ} \mathrm{N}$ & 53 & Vertical offset in Algiers Harbor \\
\hline (b) & CRAAG & $22 / 05 / 2003$ & $3.56^{\circ} \mathrm{E} / 36.80^{\circ} \mathrm{N}$ & 9 & Uprising in Zemmouri Harbor \\
\hline (c) & CTTP & $26 / 05 / 2003$ & $3.27^{\circ} \mathrm{E} / 36.79^{\circ} \mathrm{N}$ & 15.5 & $\begin{array}{l}\text { Rock fall along the Nationl road N24 } \\
\text { between Boumerdès and Dellys village. }\end{array}$ \\
\hline (d) & $\begin{array}{l}\text { Published } \\
\text { on internet }\end{array}$ & $\begin{array}{l}1 \text { st week after } \\
21 / 05 / 2003\end{array}$ & $3.90^{\circ} \mathrm{E} / 36.91^{\circ} \mathrm{N}$ & 24.5 & Coastal uplift near Delly village. \\
\hline (e) & СТTP & $24 / 05 / 2003$ & $3.59^{\circ} \mathrm{E} / 36.70^{\circ} \mathrm{N}$ & 10 & $\begin{array}{l}\text { Surface cracks affecting national road } \\
\text { N24D south of Zemmouri village. }\end{array}$ \\
\hline (f) & $\begin{array}{l}\text { Bouhadad } \\
\text { et al. } 2004\end{array}$ & $\begin{array}{l}\text { 1st week after } \\
21 / 05 / 2003\end{array}$ & $3.67^{\circ} \mathrm{E} / 36.77^{\circ} \mathrm{N}$ & 6.5 & $\begin{array}{l}\text { Occurrence of liquefaction phenomenon } \\
\text { in cracks of more than } 10 \text { meters of length } \\
\text { in a tree planting. }\end{array}$ \\
\hline (g) & CRAAG & $24 / 05 / 2003$ & $3.70^{\circ} \mathrm{E} / 36.74^{\circ} \mathrm{N}$ & 10 & $\begin{array}{l}\text { Liquefaction-induced sand boils } \\
\text { close de Isser river. }\end{array}$ \\
\hline (h) & CRAAG & $24 / 05 / 2003$ & $3.70^{\circ} \mathrm{E} / 36.79^{\circ} \mathrm{N}$ & 7 & $\begin{array}{c}\text { Tension cracks caused by lateral spreading } \\
\text { of the river bank at Oued Isser }\end{array}$ \\
\hline
\end{tabular}

Table 3. Complementary information about photos shown in Figure 4. CRAAG: Centre de Recherche en Astronomie Astrophysique et Géophysique; CTTP: Control Technique des Travaux Publiques/ Technical Control of Public Works. 
ondary effects in ESI-2007 scale). In order to systematically describe the EEEs of the Boumerdès event, we follow the classification recommended in the ESI guidelines [Michetti et al. 2007], where environmental effects are categorized in two main types: primary effects and secondary effects.

\subsection{Primary effects}

These effects concern regional markers of uplift or subsidence related to tectonic deformation, which can range from local (next to the fault) to regional scale [Audemard and Michetti 2011]. They are reported in ESI-2007 scale as primary effect. In the study area, coastal uplift was the most spectacular phenomenon generated by the Boumerdès earthquake and observed on the coastline (Figure 3). The main shock induced seafloor uplift of about $0.55 \mathrm{~m}-0.7 \mathrm{~m}$ along a $40 \mathrm{~km}$ long section near Zemmouri between Boumerdès and Dellys next to the epicenter area [Meghraoui et al. 2004]. Along the shoreline, a white band representing the thickness of algae that was under the water before the occurrence of the earthquake was observed indicating permanent shoreline uplift (Figure $4 \mathrm{~d}$ ). In addition, damages related to this phenomenon affected Zemmouri and Algiers harbors (Figure 4a,b).

\subsection{Secondary effects}

This category describes mostly shaking-induced phenomena including soft sediment deformation such as soil liquefaction, cracks, mass movements and fallen precarious rocks. In the study area, these effects are mainly concentrated in the area corresponding to the isoseists X to VIII (EMS98 scale; Harbi et al. [2007b]) (Figure 3), up to $45 \mathrm{~km}$ away from the epicenter.

\section{Slope movements and ground cracks}

In geotechnical terms, no landslides were triggered by the earthquake. Slope failures have been identified locally along roadsides between Ain Taya and Boumerdès, Zemmouri and Leghata, and Dellys and Tigzirt villages (Table 3 and Figure 4). Lateral spreading that affected the Isser River banks (Figure 4h) were numerous. We found five localities, each of them not exceeding $10 \mathrm{~m}^{2}$ of affected area. On the other hand, road cut failures and ground cracking (Figure 4e,f) were abundant in the epicentral area and mostly observed along the coast between Algiers and Tigzirt (Figure 3). The cracks sometimes reached $120 \mathrm{~m}$ of length and show vertical displacements from 4 to $10 \mathrm{~cm}$ (Figure 4e). Few direction measurements were recorded on these cracks. $\mathrm{N} 25^{\circ} \mathrm{E}$ and $\mathrm{N} 10^{\circ} \mathrm{E}$ directions were measured south to Boumerdès, whereas $\mathrm{N} 130^{\circ} \mathrm{E}$ direction was noted $10 \mathrm{~km}$ east of Boumerdès near the coastline [Bouahadad et al. 2004].

\section{Liquefaction}

This phenomenon was observed inside the epicental area, between Boumerdès and Dellys in coastal localities and along the Isser and Sebaou River banks and far from the epicentral area in Algiers Bay (Figure 3). An excessive amount of sand was ejected during the formation of sand boils near Zemmouri (Figure 4g). Different forms and sizes of liquefaction features were encountered: sand boils, sand vents observed on flat land near Isser River (Figure 3), and mud ejections through cracks (Figure 4f,g,h). A spectacular crater of boiled sand was observed in a well of $12 \mathrm{~m}$ depth and $2 \mathrm{~m}$ of diameter near Dellys village [Bouhadad et al. 2004]. The dimensions of circular liquefaction features vary from few centimeters to $1 \mathrm{~m}$ in diameter. Sometimes liquefied sand was found to have spread through cracks of several meters length. In Leghata village west of Zemmouri, a crack reached $1 \mathrm{~km}$ length.

\section{Rock falls}

Since the epicental area is a coastal flat alluvial plain, rock falls were only identified far away from the epicentral area mainly in the Atlas thrust belt. They affected precarious rocks in the Chiffa (south of Blida) and Lakhdaria Gorges, and also in many localities in Algiers province where steep terrain prevails (Figure 3, Table 2).

\section{Turbidity currents}

This category of effects includes remobilized and redeposited sediments (turbidites) and transported rock fragments. The Bourmedès main shock triggered turbidity currents that severed numerous major offshore communication cables. 29 breakpoints were counted over a distance of $150 \mathrm{~km}$ between Algiers and Azzefoun (Figure 3). The cable breaks occurred between $36 \mathrm{~min}$ and 3 h 48 min after the earthquake event as far away as $70 \mathrm{~km}$ from the coastline [Cattaneo et al. 2012]. The same phenomenon was observed off the coast of Ténès following the Orléansville (Algeria) earthquake (1954, Ms 6.7) [Heezen and Ewing 1955, Babonneau et al. 2012].

\section{Tsunami waves}

Macroseismic surveys conducted immediately after the earthquake and based on eyewitness accounts indicated a 100-200 m withdrawing sea along $50 \mathrm{~km}$ from Corso to Dellys which lasted for 20 minutes [Harbi et al. 2007b]. The Balearic Islands recorded tsunami waves that reached approximately $2 \mathrm{~m}$ of height and caused some moderate damage to boats in the harbors of the region. This phenomenon was detected in tide gauges of the western Mediterranean [Alasset et al. 2006], and an intensity of 3 was attributed to this event in the EuroMediterranean tsunami catalogue (EMTC) [Maramai et al. 2014]. 


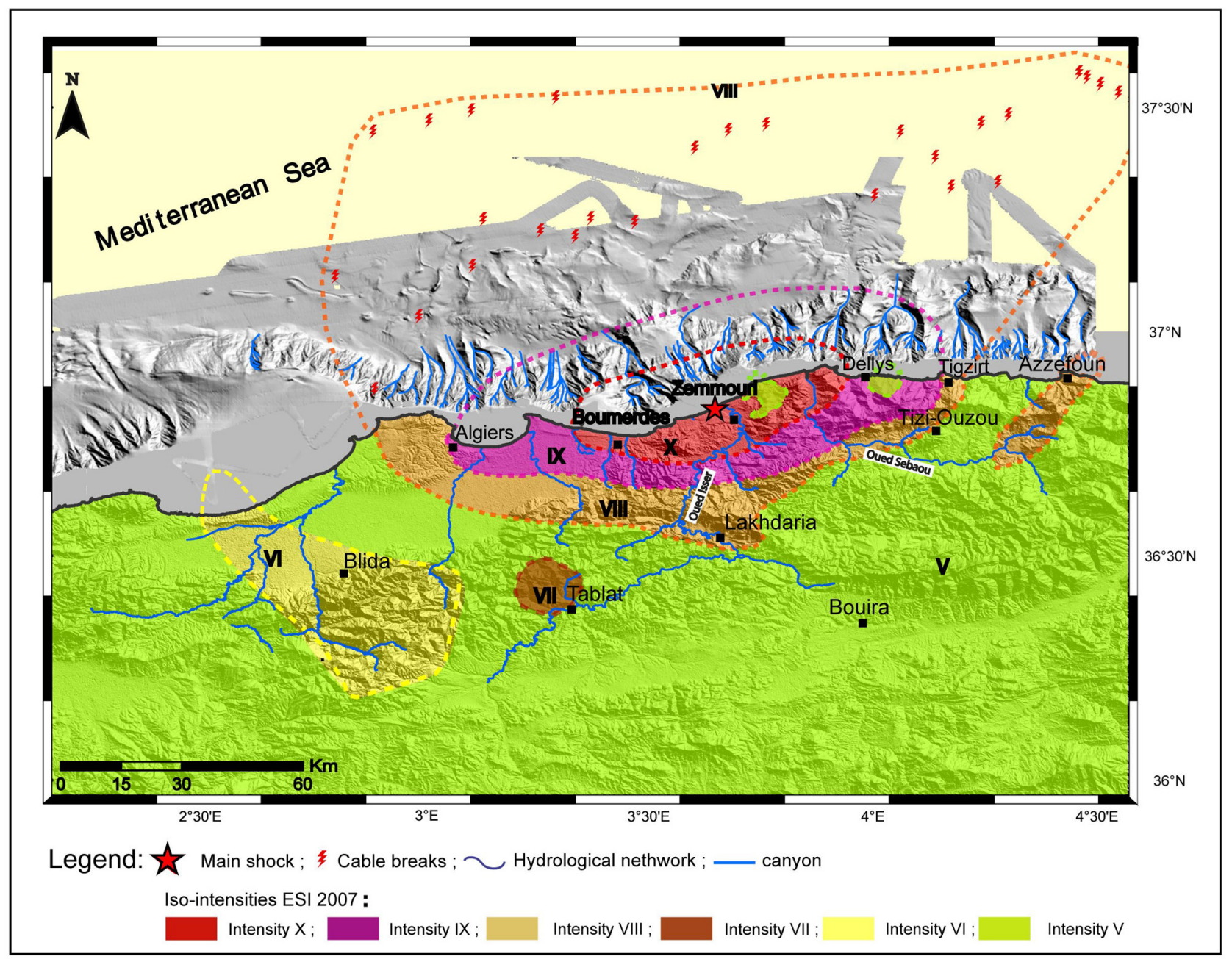

Figure 5. ESI local intensity map of the Boumerdès earthquake based on the ESI2007 scale. The colored dashed lines represent the supposed extension of the intensities offshore.

\section{Hydrological anomalies}

Hydrological effects exceed the epicentral area of Boumerdès earthquake (Figure 3 ). The testimonies of eyewitnesses indicated several anomalies particularly at water sources and well levels in many provinces such as Algiers, Blida, and Tizi-Ouzou. In the epicentral area, a spring dried up south to Zemmouri, Boumerdès, or in Corso and Djamaa N'sharidj close to Oued Isser, while a hot spring appeared in Chaabet village close to Oued Sebaou. An increase of flow springs occurred at Cheraga in Algiers Province [Harbi et al. 2007b]. Unfortunately, testimonies did not provide further details.

\section{Discussion}

All EEEs except surface ruptures are represented in our analysis of the 2003 Boumerdès earthquake. It is clear that the local geological conditions play a major role in the distribution of damage. This particularly concerns the areas where unconsolidated soil is likely to liquefy during earthquakes or areas situated on high reliefs subject to slope movement. Thus, the distribution of ground effects appears very useful in seismic hazard assessment and mapping is a valuable tool for land use planning [Grützner et al. 2013]. This involves the identification of vulnerable areas in terms of site effects, especially in large urban centers such as Algiers, with its high population density and many critical facilities.

We produced a map of the ESI-2007 macroseismic intensities and assess the Boumerdès earthquake intensity following the ESI-2007 guidelines [Michetti et al. 2007]. The total areal distribution of secondary effects is $4500 \mathrm{~km}^{2}$. This includes the onshore and the offshore domains (Figure 3). On land, the area affected covers Algiers, Lakhdaria, Tizi ouzou and Tigzirt. Offshore, we have limited our area to the canyons in front of the shoreline, where turbidity currents have been triggered. Other parameters important for estimating the intensity are the uplift of $70 \mathrm{~cm}$ in Zemmouri harbor [Bouhadad et al. 2004] close to the epicenter, and the tsunami waves that reached $2 \mathrm{~m}$ at the Balearic Islands. According to the ESI-2007 chart, the epicentral intensity $\left(I_{0}\right)=X$ occurred in the localities of Boumerdès, Zemmouri, and Dellys (Figure 5). In that area many soil liquefactions, 
cracks and slope movements were mapped along the Sebaou and Isser River banks, however some locations within this area did not record any ground effects. This is the case in the vicinities of Tigzirt and Delly (Figure 5) where volcanic and metamorphic rocks form favorable building ground. This intensity information could not have been provided with other intensity scales that reflect only resistance of the infrastructures against earthquakes.

\section{Conclusion}

By reappraisal of the Boumerdès earthquake with the ESI-2007 scale, we introduce this scale based solely on ground effects alongside traditional intensity scales to better assess seismic hazard in Algeria.

In this study, most ground effects are concentrated west of the epicental area and show a NE-SW trend. This is in agreement with a causative fault striking NESW [Delouis et al. 2004] (Figure 2). We show that it is possible to integrate earthquake environmental effects both onshore and offshore. The estimated intensity is in agreement with that assessed using the EMS-98 scale. The results of this work thus prove that the ESI-2007 scale is a reliable tool despite some difficulties persist. Indeed, at that time the post-earthquake field surveys were more focused on the man-made structures (mainly buildings). This explains the lack of accuracy on some ground effects.

We plan to apply this method to other historical earthquakes that occurred in sparsely populated areas. This strategy will improve the Algerian catalogue of historical seismicity given that the oldest known event that hit Algiers occurred in 1365. The identification of paleoEEEs will expand the time window to analyze the return period of large earthquakes, which remains unclear at present. For these reasons, there is a need to conduct further paleo-EEEs and paleoseismology investigations in order to improve the knowledge on seismic hazard in this part of the western Mediterranean.

Acknowledgements. This research was produced in the framework of the E011/08/ Centre of Research of Astronomy, Astrophysics and Geophysics (CRAAG) project. Bathymetric data are from the cruises MARADJA2003 and MARADJA2005 of the R/V Le Suroît. We are grateful to Sabina Porfido for discussions and for encouragements concerning the application of the ESI 2007 scale. We wish to thank the anonymous reviewers, Associate Editor and Sector Editor for their valuable comments and suggestions to improve this paper.

\section{References}

Alasset, P.J., H. Hébert, S. Maouche, V. Calbini and M. Meghraoui (2006). The tsunami induced by the 2003 Zemmouri earthquake (Mw $=6.9$, Algeria): Modelling and results, Geophys. J. Int., 166, 213-226.
Allen, C.R. (1975). Geological criteria for evaluating seismicity, Bull. Geol. Soc. Am., 86 (8), 1041-1057.

Ambraseys, N., and J. Vogt (1988). Material for the investigation of the seismicity of the region of Algiers, Eur. Earthq. Eng., 3, 198.

Audemard, F., and A.M. Michetti (2011). Geological criteria for evaluating seismicity revisited. Forty years of paleoseismic investigations and the natural record of past earthquakes, Geol. S. Am. S., 479, 121; doi:10.1130/2011.2479(00).

Audemard, F., T. Azuma, F. Baiocco, S. Baize, A.M. Blumetti, E. Brustia, J. Clague, V. Comerci, E. Esposito, L. Guerrieri, A. Gurpinar, C. Grützner, K. Jin, Y.S. Kim, V. Kopsachilis, M. Lucarini, J. Mc Calpin, A.M. Michetti, B. Mohammadioun, N.A. Morner, K. Okumura, Y. Ota, G. Papathanassiou, S. Pavlides, R. Perez Lopez, S. Porfido, K. Reicherter, M.A. Rodríguez Pascua, E. Roghozin, A. Scaramella, L. Serva, P.G. Silva, M. Sintubin, R. Tatevossian and E. Vittori (2015). Earthquake Environmental Effect for seismic hazard assessment: the ESI intensity scale and the EEE Catalogue, Memorie Descrittive Della Carta Geologica d'Italia, XCVII, Editor: L. Guerrieri.

Ayadi, A., C. Dorbath, F. Ousadou, S. Maouche, M. Chikh, M.A. Bounif and M. Meghraoui (2008). Zemmouri earthquake rupture zone ( $\mathrm{Mw}$ 6.8, Algeria): Aftershocks sequence relocation and $3 \mathrm{D}$ velocity model, J. Geophys. Res., 113, B09301; doi:10. 1029/2007JB005257.

Babonneau, N., A. Cattaneo, B. Savoye, G. Barjavel, J. Déverchère and K. Yelles (2012). The kramis deep-sea fan off western Algeria: Role of sediment waves in turbiditic levee growth, SEPM (Society for Sedimentary Geology), 293-308; ISBN 978-1-56576-304-3.

Beldjoudi, H., B. Delouis, A. Heddar, O. Nouar and A. Yelles-Chaouche (2011). The Tadjena earthquake $(\mathrm{Mw}=5.0)$ of December 16, 2006 in the Cheliff Region (northern Algeria): waveform modelling, regional stresses, and relation with the Boukadir Fault, Pure Appl. Geophys.; http:/ / dx.doi.org/10.1007/ s00024-011-0337-8.

Benouar, D. (1994). Materials for the investigation of the seismicity of Algeria and adjacent regions during the twentieth century, Annali di Geofisica, Special issue, 37 (4), 459-860.

Boudiaf, A. (1996). Etude sismotéctonique de la région d'Alger et de la Kabylie (Algérie): Utilisation des modèles numériques de terrain (MNT) et de la télédétection pour la reconnaissance des structures tectoniques actives: contribution à l'évaluation de l'aléa sismique, Ph.D. thesis, Montpellier II University, 268 p.

Bouhadad, Y., A. Nour, A. Slimani, N. Laouami and D. 
Belhai (2004). The Boumerdès (Algeria) earthquake of May 21, $2003\left(\mathrm{M}_{\mathrm{W}}=6.8\right)$ : Ground deformation and intensity, J. Seismol., 8, 497-506.

Bounif, A., C. Dorbath, A. Ayadi, M. Meghraoui, H. Beldjoudi, N. Laouami, M. Frogneux, A. Slimani, J.P. Alasset, A. Kharroubi, F. Oussadou, M. Chikh, A. Harbi, S. Larbes and S. Maouche (2004). The 21 May 2003 Zemmouri (Algeria) earthquake Mw 6.8: Relocation and aftershock sequence analysis, Geophys. Res. Lett., 31, L19606; doi:10.1029/2004GL020586.

Carminati, E., M.J.R. Wortel, W. Spakman and R. Sabadini (1998). The role of slab detachment process in the opening of the western central Mediterranean basins: some geological and geophysical evidence, Earth Planet. Sc. Lett., 160, 651-665.

Cattaneo, A., N. Babonneau, G. Ratzov, G. Dan-Unterseh, K. Yelles, R. Bracèn, B. Mercier de Lépinay, A. Boudiaf and J. Déverchère (2012). Searching for the seafloor signature of the 21 May 2003 Boumerdès earthquake offshore central Algeria, Nat. Hazards Earth Syst. Sci., 12, 2159-2172; doi:10.5194/nhess12-2159-2012.

Delouis, B., M. Vallée, M. Meghraoui, E. Calais, S. Maouche, K. Lammali, A. Mahsas, P. Briole, F. Benhamouda and K. Yelles (2004). Slip distribution of the 2003 Boumerdès-Zemmouri earthquake, Algeria, from teleseismic, GPS, and coastal uplift data, Geophys. Res. Lett., 31, L18607; doi:10.1029/2004G L020687.

Deschamps, A., Y. Gaudemer and A. Cisternas (1982). The El Asnam, Algeria, earthquake of 10 October 1980: multiple source mechanism determined from long period record, B. Seismol. Soc. Am., 72, 11111128.

Déverchère, J., K. Yelles, A. Domzig, B. Mercier de Lépinay, J. P. Bouillin, V. Gaullier, R. Bracène, E. Calais, B. Savoye, A. Kherroubi, P. Le Roy, H. Pauc and G. Dan (2005). Active thrust faulting offshore Boumerdès Algeria, and its relations to the $2003 \mathrm{Mw}$ 6.9 earthquake, Geophys. Res. Lett., 32, L04311; doi:10.1029/2004GL021646.

Déverchère, J., B. Mercier de Lépinay, A. Cattaneo, P. Strzerzynski, E. Calais, A. Domzig and R. Bracene (2010). Comment on "Zemmouri earthquake rupture zone (Mw 6.8, Algeria): Aftershocks sequence relocation and 3D velocity model" by A. Ayadi et al., J. Geophys. Res., 115, B04320; doi:10.1029/2008 jb006190.

Domzig, A., A.-K. Yelles, C. Le Roy, J. Déverchère, J.-P. Bouillin, R. Bracene, B. Mercier de Lépinay, P. Le Roy, E. Calais, A. Kherroubi, V. Gaullier, B. Savoye and H. Pauc (2006). Searching for the Africa-Eurasia Miocène boundary offshore western Algeria
(MARADJA'03 cruise), C. R. Geosci., 338, 80-91.

Duggen, S., K. Hoernle, P. Van den Bogaard and C. Harris (2004). Magmatic evolution of the Alboran region: the role of subduction in forming the western Mediterranean and causing the Messinian Salinity Crisis, Earth Planet. Sc. Lett., 218, 91-108.

Durand-Delga, M. (1969). Mise au point sur la structure du Nord-Est de la Berberie, Bulletin of Geological Algeria Card Service, 39, 89-131; doi:10.1007/s1095 0-013-9400-5

Ferdi, S., and A. Harbi (2013). Roman literary and epigraphic sources for the study of historical seismicity in Algeria circa 42-420 AD, J. Seismol.; doi:10.1007/ s10950-013-9400-5

Frizon De Lamotte, D., B. Saint Bezar, R. Bracene and E. Mercier (2000). The two main steps of the Atlas building and geodynamics of the western Mediterranean, Tectonics, 19, 740-761.

Grünthal, G. (2001). L'échelle Macrosismique Européenne 1998, Cahiers du Centre Européen de Géodynamique et de Séismologie, 19, $103 \mathrm{p}$.

Grützner, C., S. Barba, I. Papanikolaou and R. PérezLópez (2013). Earthquake geology: science, society and critical facilities, Annals of Geophysics, 56 (6), S0683; doi:10.4401/ag-6503.

Gueguen, E., C. Doglioni and M. Fernandez (1998). On the post-25 Ma geodynamic evolution of the western Mediterranean, Tectonophysics, 298, 259-269.

Guemache, M.A., H. Djellit, H. Yemmel, S. Gharbi and C. Dorbath (2010). La faille post-astienne de BouinanSoumâa (région de Blida, bordure Sud du bassin de la Mitidja (Algérie): expression néotectonique et implication dans l'évaluation de l'aléa sismique, Bulletin du Service Géologique National, 21 (1), 75-94, 11 fig.

Harbi, A., S. Maouche, A. Ayadi, D. Benouar, G.F. Panza and H. Benhallou (2004). Seismicity and tectonics structures in the site of Algiers and its surroundings: a step towards microzonation, Pure Appl. Geophys., 161, 949-967.

Harbi, A., S. Maouche, F. Vaccari, A. Aoudia, F. Oussadou, G.F. Panza and D. Benouar (2007a). Seismicity, seismic input and site effects in the Sahele Algiers region (North Algeria), Soil Dyn. Earthq. Eng., 27 (5), 427-447.

Harbi, A., S. Maouche, F. Ousadou, Y. Rouchiche, A. Yelles-Chaouche, M. Merahi, A., Heddar, O. Nouar, A. Kherroubi, H. Beldjoudi, A. Ayadi and D. Benouar (2007b). Macroseismic study of the Zemmouri earthquake 21 May 2003 (Mw 6.8, Algeria). Earthq. Spectra, 23 (2), 315-332.

Heddar, A., C. Authemayou, H. Djellit, A.K., Yelles, J. Déverchère, S. Gharbi, A. Boudiaf and B. Van Vliet Lanoe (2013). Preliminary results of a paleoseismo- 
logical analysis along the Sahel fault (Algeria): new evidence for historical seismic events, Quatern. Int., 302, 201-223; doi:10.1016/j.quaint. 2012.09.07.

Heezen, B.C., and M. Ewing (1955). Orléansville earthquake and turbidity currents, AAPG Bulletin, 39, 2505-2514.

Jolivet, L., and C. Faccenna (2000). Mediterranean extension and Africa-Eurasia collision, Tectonics, 19 (6), 1095-1106.

Kherroubi, A., J. Déverchère, A.K. Yelles, B. Mercier de Lépinay, A. Domzig, A. Cattaneo, R. Bracene, V. Gaullier and D. Graindorge (2009), Recent andactive deformation pattern off the easternmost Algerian margin, western Mediterranean Sea: new evidence for contractional Tectonic reactivation, Mar. Geol., 261 (1-4), 17-32; doi:10.1016/j.margeo.2008.05.016.

Laouami, N., A. Slimani, Y. Bouhadad, J.L. Chatelain and A. Nour (2006). Evidence for fault-related directionality and localized site effects from strong motion recordings of the 2003 Boumerdes (Algeria) earthquake: Consequences on damage distribution and the Algerian seismic code, Soil Dyn. Earthq. Eng., 26, 991-1003.

Maouche, S., M. Meghraoui, C. Morhange, S. Belabbes, Y. Bouhadad and H. Haddoum (2011). Active coastal thrusting and folding, and uplift rate of the Sahel Anticline and Zemmouri earthquake area (Tell Atlas, Algeria), Tectonophysics, 509 (1-2), 69-80.

Mauffret, A., D. Frizon de Lamotte, S. Lallemant, G. Gorini and A. Maillard (2004). E-W opening of the Algerian Basin (West Mediterranean), Terra Nova, 16, 257-264.

Maramai, A., B. Brizuela and L. Graziani (2014). The Euro-Mediterranean Tsunami Catalogue. Annals of Geophysics, 57 (4), S0435; doi:10.4401/ag-6437.

Meghraoui, M., A. Cisternas and H. Philip (1986). Seismotectonics of the lower Cheliff basin: structural background of the El Asnam (Algeria) earthquake, Tectonics, 6, 1-17.

Meghraoui, M., H. Philip, F. Albarede and A. Cisternas (1988). Trench investigations through the trace of the $1980 \mathrm{El}$ Asnam thrust fault: evidence from paleoseismicity, B. Seismol. Soc. Am., 78 (2), 979-999.

Meghraoui, M. (1991). Blind reverse faulting system associated with the Mont Chenoua-Tipasa earthquake of 29 October 1989 (north-central Algeria), Terra Nova, 3, 84-93.

Meghraoui, M., and F. Doumaz (1996). Earthquake-induced flooding and paleoseismicity of the El Asnam (Algeria) fault related fold, J. Geophys. Res., 101, 17617-17644.

Meghraoui, M., S. Maouche, B. Chemaa, Z. Cakir, A. Aoudia, A. Harbi, P.-J. Alasset, A. Ayadi, Y. Bouhadad and F. Benhamouda (2004). Coastal uplift and thrust faulting associated with the $\mathrm{Mw}=6.8$ Zemmouri (Algeria) earthquake of 21 May, 2003, Geophys. Res. Lett., 31, L19605.

Michetti, A.M., E. Esposito, A.Gurpinar, B. Mohammadioun, S. Porfido, E. Ro-gozhin, L. Serva, R. Tatevossian, E. Vittori, F .Audemard, V. Comerci, S. Marco, J. McCaplin and N.A. Morner (2004). The INQUA scale: an innovative approach for assessing earthquake intensities based on seismically induced ground effects in natural environment, Memorie descrittive della Carta Geologica d'Italia, Special paper edited by E. Vittori and V. Comerci, 67, $46 \mathrm{p}$.

Michetti, A.M., E. Esposito, L. Guerrieri, S. Porfido, L. Serva, R. Tatevossian, E. Vittori, F. Audemard, T. Azuma, J. Clague, V. Comerci, A. Gürpinar, J. Mc Calpin, B. Mohammadioun, N.A. Mörner, Y. Ota. and E. Roghozin (2007). Environmental Seismic Intensity Scale 2007 - ESI 2007, In: L. Guerrieri and E. Vittori (eds.), Intensity Scale ESI 2007, Memorie descrittive della Carta Geologica d'Italia, 74, 7-54.

Mokrane, A., A. Ait Messaoud, A. Sebaï, A. Ayadi, M. Bezzeghoud and H. Benhallou (1994). Les séismes en Algérie de 1365 à 1992, Publication du Centre de Recherche en Astronomie, Astrophysique et Géophysique (C.R.A.A.G), Algiers, Algeria, 277 p.

Morel, J.L., and M. Meghraoui (1996). The GoringeAlboran-Tell (Galtel) tectonic zone: A transpression system along the Africa-Eurasia plate boundary, Geology, 24, 755-758.

Papanikolaou, I.D., D.I. Papanikolaou and E.L. Lekkas (2009). Advances and limitations of the Environmental Seismic Intensity scale (ESI 2007) regarding near-field and farfield effects from recent earthquakes in Greece: implications for the seismic hazard assessment, In: K. Reicherter, A.M. Michetti and P.G. Silva Barroso (eds.), Palaeoseismology: Historical and Prehistorical Records of Earthquake Ground Effects for Seismic Hazard Assessment, The Geological Society, London, Special Publ., 316, 11-30.

Porfido, S., E. Esposito, E. Vittori, G. Tranfaglia, L. Guerrieri and R. Pece (2007). Seismically induced ground effects of the 1805, 1930 and 1980 earthquakes in the Southern Apennines (Italy), Boll. Soc. Geol. It. (Ital. J. Geosci.), 126 (2), 333-346.

Reicherter, K., A.M. Michetti and P.G. Silva (2009). Palaeoseismology: Historical and Prehistorical Records of Earthquake Ground Effects for Seismic Hazard Assessment, Geological Society of London Special Publication, 316, $320 \mathrm{p}$.

Rothé, J.P. (1950). Les Séismes de Kherrata et la simicité de l'Algérie, Bulletin of Geological Algeria Card Service, 4th Series, Geophysics, 3, 40. 
Schettino, A., and E. Turco (2006). Plate kinematics of the Western Mediterranean region during the Oligocene and Early Miocene, Geophysi. J. Int., 166, 1398-1423.

Serpelloni, E., G. Vannucci, S. Pondrelli, A. Argnani, G. Casula, M. Anzidei, P. Baldi and P. Gasperini (2007). Kinematics of the Western Africa-Eurasia plate boundary from focal mechanisms and GPS data, Geophys. J. Int., 169 (3), 1180-1200.

Serva, L., E. Esposito, L. Guerrieri, S. Porfido, E. Vittori and V. Comerci (2007). Environmental effects from five historical earthquakes in Southern Apennines (Italy) and macroseismic intensity assessment: Contribution to INQUA EEE Scale Project, Quatern. Int., 173-174, 30-44.

Strzerzynski, P., J. Déverchère, A. Cattaneo, A. Domzig, K. Yelles, B. Mercier de Lépinay, N. Babonneau and A. Boudiaf (2010). Tectonic inheritance and PliocenePleistocene inversion of the Algerian margin around Algiers: Insights from multibeam and seismic reflection data, Tectonics, 29, TC2008; doi:10.1029/ 2009TC002547,

Thomas, G. (1976). Mise en évidence de décrochements dextres Est-Ouest d'âge quaternaire en Algérie nord occidentale, Comptes rendus de l'Académie des sciences de Paris, France, série D, 283, 893-896.

Thomas, G. (1985). Géodynamique d'un bassin intra montagneux, le bassin du bas Chelif, Thèse de doctorat es sciences, Université de PAU (France).

Vergès, J., and F. Sabàt (1999). Constraints on the Western Mediterranean kinematics evolution along a $1000-\mathrm{km}$ transect from Iberia to Africa, In: B. Durant, L. Lolivet, F. Horvarth and M. Séranne (eds.), The Mediterranean Basin: Tertiary Extensions within the Alpine Orogen, Geological Society of London, Special Publication, 156, 63-80.

Yelles-Chaouche, A.K., A. Deramchi, A. Ferkoul and K. Aoulaiche (2002). Les séismes d'Algérie du Nord de 1992-2001, Catalogue of Centre de Recherche en Astronomie, Astrophysique et Géophysique (CRAAG), Algeria, $216 \mathrm{p}$.

Yelles-Chaouche, A.K., H. Djellit and M. Hamdache (2003). The Boumerdès-Algiers (Algeria) earthquake of May 21, 2003 (Mw =6.8), CSEM/EMSC Newsl., 20, 3-5.

Yelles, A.K., A. Boudiaf, H. Djellit and R. Bracène (2006). La tectonique active de la region nord-algérienne, C. R. Geosci., 338, 126-139.

Yelles-Chaouche, A.K., A. Deramchi, A. Ferkoul, K. Aoulaiche, K. Malki and K. Meghnine (2011). Les séismes d'Algérie du Nord 2002-2011, Catalogue of Centre de Recherche en Astronomie, Astrophysique et Géophysique (CRAAG), Algeria.

\footnotetext{
^Corresponding author: Aicha Heddar, Centre de Recherche en Astronomie Astrophysique et Géophysique (CRAAG), Bouzareah-Algiers, Algeria; email: a.heddar@craag.dz.

(C) 2016 by the Istituto Nazionale di Geofisica e Vulcanologia. All rights reserved.
} 